Plant Tissue Cult. \& Biotech. 25(1): 15-23, 2016 (June)

$\overline{\text { PTC\&B }}$

\title{
Assessment of Acid Phosphatase Production by In vitro Cultures of Atropa acuminata
}

\author{
Saima Khan ${ }^{3}$, Meenu Katoch ${ }^{1,4}$, Sharada Mallubhotla ${ }^{3}$, Suphla \\ Gupta $^{2,4}$, Manju Sambyal and Ashok Ahuja ${ }^{4 *}$ \\ Plant Tissue Culture Group, CSIR-Indian Institute of Integrative Medicine, \\ Jammu-180001, India
}

Key words: Acid phosphatase, Atropa acuminata, $p$-nitrophenyl phosphate, Inorganic phosphate starvation

\begin{abstract}
The potential of various culture lines of Atropa acuminata were investigated for resourcing acid phosphatase (ACP) (3.1.3.2). Crude enzyme extract comprised of a mixture of four isoforms, distinguishable by polyacrylamide gel electrophoresis (PAGE) with molecular weight ranging from 39 to $215 \mathrm{kDa}$. In vitro regenerated proliferative shoots, callus and roots showed higher specific activity $(2.49,3.41$, $2.91 \mathrm{U} / \mathrm{mg}$ protein, respectively) as compared to in vivo grown plants $(0.71 \mathrm{U} / \mathrm{mg}$ protein). ACP activity in root cultures increased progressively up to $4.6 \mathrm{U} / \mathrm{mg}$ during the entire growth period ( 2 - 24 weeks), whereas in case of shoot cultures, the specific activity escalated to $2.49 \mathrm{U} / \mathrm{mg}$ at 8 weeks, which then declined subsequently $(1.95 \mathrm{U} / \mathrm{mg})$. Similarly, callus cultures initially showed a higher phosphohydrolytic activity (3.41 U/mg protein) until 8 weeks by which period, it decreased with the passage of growth period. The present studies reveal an alternate system for resourcing of ACP from Atropa acuminata.
\end{abstract}

\section{Introduction}

Phosphohydrolases (EC 3.1.3) are a group of commercial enzymes that catalyze the hydrolysis of broad spectrum phosphate esters and anhydrides. Microorganisms and snake venoms are potent commercial sources of this class of enzyme

*Author for correspondence: <ahujarrljm@gmail.com>. Present address: Plant Molecular Biology \& Biotechnology, RVSKVV-College of Agriculture, Gwalior 474002, India. 'Biotechnology Division, CSIR-Indian Institute of Integrative Medicine, Jammu-180001, India. ${ }^{2}$ Plant Biotechnology Division, CSIR-Indian Institute of Integrative Medicine, Jammu-180001, India. ${ }^{3}$ Department of Biotechnology, Shri Mata Vaishno Devi University, Katra-182320, India. ${ }^{4}$ Academy of Scientific and Industrial Research, CSIR-Indian Institute of Integrative Medicine, Jammu-180001, India. 
(Utika et al. 1973). Phosphohydrolases are involved in a multitude of biological functions ranging from antibacterial action to bone metabolism in animals to phosphate uptake in plants. In plants, their possible role in phosphate mobilization during seed germination and seedling growth has been reported (De-Kundu and Banerjee 1990). Phosphohydrolases are commercially utilized as food additives (Andrews 1991), biochemical reagents (Su 1995) and potential therapeutic targets (Bull et al. 2002). Since inosine-5'-monophosphate and guanosine-5'-monophosphate have strong flavor enhancing activities, phosphohydrolases find wide application in production of free nucleotides and nucleosides from RNA (Utika et al. 1973). Plants have developed many adaptive mechanisms to enhance their availability, thereby increasing the uptake of inorganic phosphate $\left(\mathrm{P}_{\mathrm{i}}\right)$ under enduring $\mathrm{P}_{\mathrm{i}}$ deficit conditions. One such adaptive mechanism is production and secretion of ACPs to release $P_{i}$ from organic forms (Goldstein et al. 1988). Plant ACPs have been isolated and characterized from several sources such as seeds (Granjeiro et al. 1999), roots (Panara et al. 1990), leaves(Staswick et al. 1994) and fruits (Turner and Plaxton 2001). Some of these have also been crystallized (Sträter et al. 1992). These enzymes, either homo- or heterodimeric glycoproteins, exist as intracellular (localized in cytoplasm and vacuole) or extracellular (localized in cell wall) isoforms that can markedly differ in their molecular weight, substrate specificity and their susceptibility to inhibition by various compounds such as molybdate, phosphate, vandate, fluoride, etc. (Ferriera et al. 2000, Ehsanpour and Amini 2003). Plant tissue culture systems provide a better alternative for the production of these enzymes. Microbial cultures are not the preferred choice for particular enzymes like ACP, which are usually active in their glcosylated form and in some cases, misfolding of proteins in bacteria and hyperglycosylation of proteins in fungi may occur (Harashima 1994), thereby making plant cultures an alternative and more valuable system or resource for these enzymes. Field grown plants are not preferred as a source for the industrial production of plant enzymes due to the presence of polyphenols, which leads to poor enzymatic yields. Reports have proved the ability of cell suspension cultures of Nicotiana tabacum (Buitelar and Tramper 1992) and Catharanthus roseus (Tanaka et al. 1985) as the most promising source for production of phosphohydrolases. The present communication describes screening of in vitro regenerated morphogenetic lines of Atropa acuminata for the production of ACPs, which could be further exploited commercially for resourcing this important enzyme. 


\section{Materials and Methods}

In vitro regenerated morphogenetic lines of calli and plantlets of Atropa acuminataas described earlier (Ahuja et al. 2002) and the candidate plant grown in vivo were utilized during the present study to screen for ACP enzyme activity. Heterogeneous cell suspensions were routinely cultured in $50 \mathrm{ml}$ MS supplemented with BAP and NAA (each $1 \mathrm{mg} / \mathrm{l}$ ) and $170 \mathrm{mg} / \mathrm{l}$ of $\mathrm{P}_{\mathrm{i}}$ as control which is described as the optimal concentration $\left(+\mathrm{P}_{\mathrm{i}}\right.$ ) over 8 days (Bozzo et al. 2002). $\mathrm{Pi}_{\mathrm{i}-}$ starvation treatments were given after 8 days in which $+P_{i}$ cells were washed with $P_{i}$ deficient MS. These cells were inoculated into five separate flasks containing different $P_{i}$ concentrations (1.5, 3.0, 6.0 and $\left.12 \mathrm{mM}\right)$. Over a 16 day growth period, the cells were harvested by filtration through Whatman filter paper $(0.45 \mu \mathrm{m})$ on a Buchner funnel and cell extracts prepared for ACP assay.

ACP activity in plant samples were determined according to procedure described by Dolapchiev and Bakalova (1982) using $p$-nitrophenyl phosphate ( $p$ NPP) as substrate, which corresponds to phosphomonoesterase activity in particular. Fresh tissue $(1 \mathrm{~g})$ was macerated in a chilled pestle and mortar at $4^{\circ} \mathrm{C}$ in liquid nitrogen and extraction buffer $(0.05 \mathrm{M}$ sodium acetate buffer $\mathrm{pH} 5.4$, $0.5 \%$ ascorbic acid, $1 \mathrm{mM}$ PMSF) was added. After homogenization, the slurry was centrifuged at 10,000 rpm for $20 \mathrm{~min}$ at $4^{\circ} \mathrm{C}$. The clear supernatant (extracted sample) obtained was used for the enzyme assay, which consisted of $200 \mu \mathrm{l}$ of $0.05 \mathrm{M}$ sodium acetate buffer ( $\mathrm{pH} 5.4$ ), $200 \mu \mathrm{l}$ of $20 \mathrm{mMp}-\mathrm{NPP}$ and $100 \mu \mathrm{l}$ of extracted sample. The reaction mixture was incubated at $25^{\circ} \mathrm{C}$ for $30 \mathrm{~min}$ and reaction terminated by adding $2.5 \mathrm{ml}$ of $0.1 \mathrm{M} \mathrm{NaOH}$ and absorbance was measured spectrophotometerically at $410 \mathrm{~nm}$. The concentration of the extracted enzyme was calculated by extrapolation on a standard curve. The standard used in this study was para-nitrophenol $(10 \mathrm{mg} / \mathrm{ml})$ and protein concentration was determined by the Folin method (Lowry et al. 1951). Bovine serum albumin (BSA) was used as the standard protein and specific activity was calculated as enzyme units/mg $(\mathrm{U} / \mathrm{mg})$ protein.

The effect of $\mathrm{pH}$ on enzyme activity was determined by performing the hydrolysis of $p$-NPP in a series of buffers at various $\mathrm{pH}$ values ranging from 4.5 to 8.8 using $0.05 \mathrm{M}$ acetate buffer $\mathrm{pH} 4.5$ to 5.4 and Tris-Cl buffer $\mathrm{pH} 6.0$ to 8.8.

Isoforms of ACP extracted from various morphogenetic cultures, were characterized by PAGE (Native) (Davis 1964) with slight modifications. Coommassie brilliant blue $\left(\mathrm{CBB}_{250}\right)$ was used to localize protein bands with standard molecular weights (Pierce) comprising 215, 120, 84, 60, 39.2, 28 and18.3 $\mathrm{kDa}$. To visualize ACPs, the gel was incubated for $30 \mathrm{~min}$ in $0.05 \mathrm{M}$ acetate buffer $\mathrm{pH} 5.4$ containing $20 \mathrm{mM}$-NPP and $20 \mathrm{mM} \mathrm{MgCl}_{2}$. The intense yellow bands of 
para-nitrophenol were photographed immediately after stopping the reaction with $1 \mathrm{M} \mathrm{NaOH}$.

\section{Results and Discussion}

For resourcing the phosphohydrolytic enzyme, various in vitro regenerated culture lines of Atropa acuminata were analyzed to identify hyper-productive clones and compare them with field grown plant of the same age. The results demonstrated highest specific activity of the enzyme in the 8 week-old-callus (3.41 U/mg protein), roots $(2.91 \mathrm{U} / \mathrm{mg}$ protein) and proliferative shoots $(2.49$ $\mathrm{U} / \mathrm{mg}$ protein) as compared to in vivo grown plants $(0.71 \mathrm{U} / \mathrm{mg}$ protein) (Fig. 1A). The higher enzyme activity of the cultured cells may be due to the limiting phosphate concentration in the medium, which triggered the over expression of the ACP as reported earlier (Dolapchiev et al. 1996). Further, the dynamics of phosphohydrolytic enzyme activity with respect to the growth of proliferative shoots, roots and calli indicated a maximum specific activity in the callus (3.41 $\mathrm{U} / \mathrm{mg}$ protein) and a subsequent decrease in activity with increase in age of the cultures (Table 1, Fig. 1B). Values showed a decline in specific activity by almost half as the callus cultures entered 16 weeks ( $1.70 \mathrm{U} / \mathrm{mg}$ protein) to 24 weeks (1.44 $\mathrm{U} / \mathrm{mg}$ protein). The higher enzyme activity in early stages of undifferentiated callus growth suggests that the enzyme is involved in the process of dedifferentiation during callus initiation. Reports have also established phosphohydrolase as destructive enzymes involved in the process of disintegration of the inner layer of cell walls and their remodeling during growth (Ilieve et al. 2000). The activity of ACP, in root tissue increased progressively during the entire growth period from $2(2.36 \mathrm{U} / \mathrm{mg}$ protein) to 24 weeks (4.6 $\mathrm{U} / \mathrm{mg}$ protein), whereas in case of shoot cultures, the specific activity of ACP reached a maximum $(2.49 \mathrm{U} / \mathrm{mg}$ protein) until 8 weeks, after which it declined (1.92, $1.95 \mathrm{U} / \mathrm{mg}$ protein) at later stages of growth (16, 24 weeks, respectively). Increased ACP activity induced by $P_{i}$ starvation has been demonstrated in a number of plants, including Arabidopsis thaliana, Lycopersicum esculentum and Solanum tuberosum (Del et al. 1999, Bozzo et al. 2002, Zimmermann et al. 2004). Consistent with these findings, we found that ACP activity ascended while transition from $P_{i}$ sufficiency to deficiency, thereby revealing that these enzymes might be involved in phosphate acquisition and mobilization processes (Fig. 1C).

The $\mathrm{pH}$ optimum of the phosphohydrolytic enzyme estimated at different $\mathrm{pH}$, ranging from 4.5 to 8.8 , at constant temperature of $25^{\circ} \mathrm{C}$ was found to be 5.4 (11.3 U/g FW) (Fig. 1D). The enzyme activity tends to decline (5.3 U/g FW at $\mathrm{pH}$ 8.0) with the increase in $\mathrm{pH}$. Interestingly, a sharp increase (8.6 U/g FW), 
however, was observed again at $\mathrm{pH}$ 8.8. A similar activity profile was reported earlier (Dolapchiev et al. 1996, Ilieva et al. 2000).
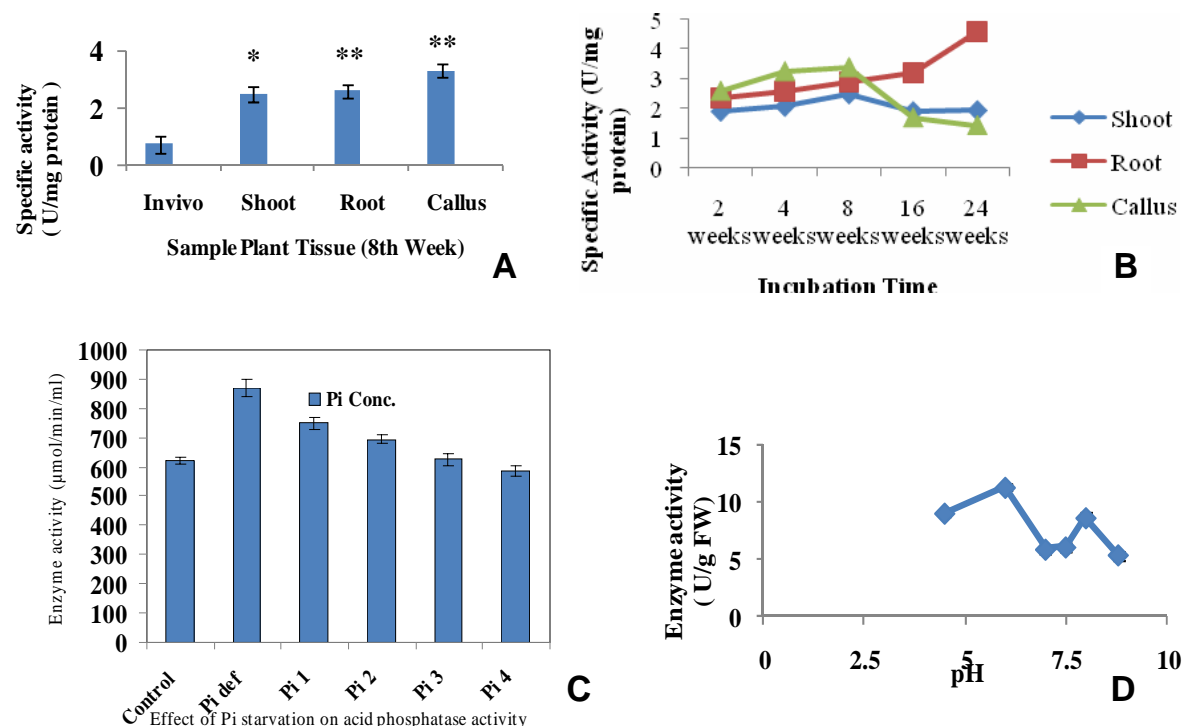

Fig. 1. Acid phosphatase (ACP) enzyme activity and Protein in Atropa acuminata. A. Specific activity of enzyme in in vivo plant and in vitro shoot, root and callus after 4 weeks. B. Enzyme activity in various culture lines at different growth stages. C. Effect of $P_{i}$ starvation on acid phosphatase activity. D. ACP activity in Atropa acuminataat different $\mathrm{pH}$ regimes.
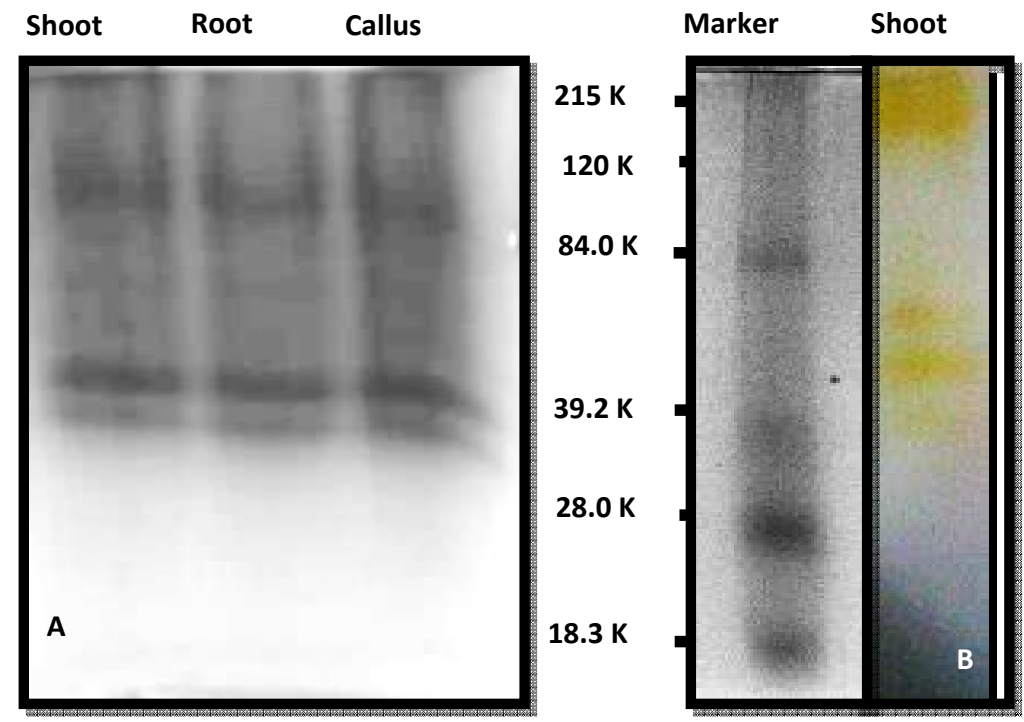

Fig. 2A. PAGE of protein extracted from in vitro tissue cultured Atropa acuminata Lane 1: shoot, lane 2: root and lane 3: callus (B) Acid phosphatase isoforms in in vitro tissue cultured shoots of Atropa acuminata, lane 1: Standard molecular weight marker (Pierce Blue Pre-stained Protein molecular weight marker mix), lane 2: Shoot extract. 
The temporal variation in ACP activity in different morphogenetic lines indicated that the maximum activity varied in different organ cultures of Atropa acuminata. The present study revealed that to get the most optimal enzymes, cultures such as roots should be maintained for 24 weeks. However, maintenance of root cultures with the aim of producing higher enzyme activity has practical difficulties and is economically unviable. On the contrary, eight-week-old calli showed a comparatively good specific activity $(3.41 \mathrm{U} / \mathrm{mg})$. Moreover, in terms

Table 1. Acid phosphatase (ACP) kinetics with respect to time course in different culture lines of Atropa acuminata.

\begin{tabular}{llccccc}
\hline \multirow{2}{*}{$\begin{array}{l}\text { Sample } \\
\text { type }\end{array}$} & Parameters & \multicolumn{5}{c}{ Time duration (weeks) } \\
\cline { 2 - 6 } analyzed & 2 & 4 & 8 & 16 & 24 \\
\hline Shoot & $\begin{array}{l}\text { Enzyme activity (U/g } \\
\text { fresh weight) }\end{array}$ & $15.48 \pm 1.1$ & $18.65 \pm 1.2$ & $22.18 \pm 2.0$ & $19.17 \pm 2.6$ & $23.35 \pm 1.6$ \\
& $\begin{array}{l}\text { Protein (mg/g fresh } \\
\text { weight) }\end{array}$ & $6.8 \pm 0.45$ & $7.5 \pm 1.0$ & $8.9 \pm 0.9$ & $10.0 \pm 0.83$ & $12.0 \pm 1.95$ \\
& $\begin{array}{l}\text { Specific activity } \\
\text { (U/mg protein) }\end{array}$ & $1.92 \pm 0.33$ & $2.08 \pm 0.26$ & $2.49 \pm 0.27$ & $1.92 \pm 0.24$ & $1.95 \pm 0.26$ \\
& $\begin{array}{l}\text { Enzyme activity (U/g } \\
\text { fresh weight) }\end{array}$ & $23.31 \pm 1.2$ & $21.3 \pm 2.0$ & $20.45 \pm 2.1$ & $9.88 \pm 1.1$ & $7.75 \pm 0.63$ \\
& $\begin{array}{l}\text { Protein (mg/g fresh } \\
\text { weight) }\end{array}$ & $6.9 \pm 0.30$ & $6.5 \pm 0.52$ & $6.0 \pm 0.60$ & $5.8 \pm 1.9$ & $5.4 \pm 1.1$ \\
& $\begin{array}{l}\text { Specific activity } \\
\text { (U/mg protein) }\end{array}$ & $2.61 \pm 0.23$ & $3.28 \pm 0.23$ & $3.41 \pm 0.25$ & $1.7 \pm 0.33$ & $1.44 \pm 0.2$ \\
& $\begin{array}{l}\text { Enzyme activity (U/g } \\
\text { fresh weight) }\end{array}$ & $4.68 \pm 0.83$ & $5.2 \pm 0.28$ & $6.4 \pm 0.30$ & $8.39 \pm 0.9$ & $13.4 \pm 1.3$ \\
& $\begin{array}{l}\text { Protein (mg/g fresh } \\
\text { weight) }\end{array}$ & $1.8 \pm 0.26$ & $2.0 \pm 0.38$ & $2.2 \pm 0.45$ & $2.6 \pm 0.33$ & $2.9 \pm 0.31$ \\
& $\begin{array}{l}\text { Specific activity } \\
\text { (U/mg protein) }\end{array}$ & $2.36 \pm 0.9$ & $2.60 \pm 0.24$ & $2.91 \pm 0.23$ & $3.21 \pm 0.26$ & $4.6 \pm 0.24$ \\
\hline
\end{tabular}

Values are the mean of three replicates \pm standard deviation. One enzyme unit is the amount of enzyme which liberates one $\mu \mathrm{mol}$ of $p$-nitro phenol per minute $(\mathrm{p} \leq 0.05,0.01)$.

of biomass, five-folds increase in calli can be produced in 24 weeks which would provide a higher enzyme activity in comparison to root tissues. As such, the present results indicate that callus cultures established from a selected line could be an obvious choice for the production of ACPs, whose activity peaks in the initial growth phase. The advantage of cell suspension cultures as an alternate method for large scale production of useful bioactive metabolites and enzymes have been well reported in fermenters utilizing Nicotiana tabacum (Buitelar and Tramper 1992, Ilieva et al. 2000). The present data of ACP activity is comparable 
to the $2.9 \mu \mathrm{kat} / \mathrm{ml}$ phosphomonoesterase activity reported for Nicotiana tabacum culture medium as reported earlier (Dolapchiev et al. 1996).

PAGE, both SDS and native, of protein extracted from all the in vitro regenerated morphogenetic lines showed a similar pattern of isoforms of ACP (Fig. 2A). Native-PAGE gel suggested four isoforms of ACP, when developed with the substrate $(p-\mathrm{NPP})$. The molecular weight of the four isoforms I-IV ranged from 39 to $215 \mathrm{kDa}$ (Fig. $2 \mathrm{~B}$ ). The marked difference in the apparent molecular weights among ACP bands strongly suggested one of them may be of a higher molecular weight or contain an oligomeric form of other protein in the lower molecular weight bands as reported for stem homogenates of Flax Genotrophs (Fieldes and Tyson 1983) root/shoot of wheat and barley calli (Chawla 1989, 1991). The study is in progress to investigate release of vacuolar ACPs extracellularly in the medium which would provide a further link between biochemical and molecular characterization of ACP isoenzymes produced by Atropa accuminata cell cultures. This would further extend an opportunity to develop rational strategies for engineering $P_{i}$ efficient plants and could also be considered for the production and regulation of ACPs and their role in higher plants.

\section{Acknowledgements}

The present paper is dedicated to the fond memory of our departed colleague, Dr. Anita Ahlawat.

\section{References}

Ahuja A, Sambyal M and Koul S (2002) In vitro propagation and conservation of Atropa acuminate Royle ex Lindl. An indigenous threatened medicinal plant. J. Plant Biochem. Biotechnol. 11: 121-124.

Andrews AT (1991) Phosphatases in food enzymology. Elsevier Applied Science I: 90-99.

Bozzo GG, Raghothama KG and Plaxton WC (2002) Purification and characterization of two secreted purple acid phosphatase isozymes from phosphate-starved tomato (Lycopersicon esculentum) cell cultures. Eur. J. Biochem. 269(24): 6278-6286.

Buitelar RM and Tramper J (1992) Strategies to improve the production of secondary metabolites with plant cell cultures: A literature review. J. Biotechnol. 23: 111-141.

Bull H, Murray PG, Thomas D, Fraser AM and Nelson PN (2002) Acid phosphatases. Mol. Pathol. 55(2): 65-72.

Chawla HS (1989) Regeneration responses of callus from different explants and changes inisozymes during morphogenesis in wheat. Biol. Plantarum. 31: 121-125.

Chawla HS (1991) Regeneration potentiality and isozymic variations during morphogenesis of barley callus. Biol. Plantarum. 33: 175-180. 
Assessment of Acid Phosphatase Production

Davis BJ (1964) Disc electrophoresis - II. Method and application to human serum proteins. Ann. NY Acad. Sci. 121: 404-427.

De-Kundu PD and Banerjee CA (1990) Multiple forms of acid phosphatase from seedling axes of Vigna radiata. Phytochem. 29: 2825-2828.

Del Pozo JC, Allona I, Rubio V, Leyva A, Pena ADL, Aragoncillo C and Paz-Ares J (1999) A type 5 acid phosphatase gene from Arabidopsis thaliana is induced by phosphate starvation and by some other types of phosphate mobilising/oxidative stress conditions. Plant J. 19: 579-589.

Dolapchiev LB and Bakalova AT (1982) Simple purification and some properties of beef spleen exonuclease. Prep. Biochem. 12: 121-136.

Dolapchiev LB, Bakalova AT, Vassileva RA, Ilieva MP and Mihneva MD (1996) Tobacco plant cell cultures with high content of extracellular phosphohydrolases. Enzyme Microbiol. Biotechnol. 19: 384-388.

EhsanpourAA and Amini F (2003) Effect of salt and drought stress on acid phosphatase activities in alfalfa (Medicago sativa L.) explants under in vitro culture. African. Biotechnology. 5: 133-135.

Ferreira CV, Taga EM and Aoyama H (2000) Inhibition of acid phosphatase isoforms purified from mature soybean (Glycine max) seeds. J. Enzyme Inhib. 15(4): 403-410.

Fieldes MA and Tyson H (1983) Molecular weight differences in acid phosphatases of stem homogenates from L and S Flax genotrophs. Biochemical Genet. 21: 391-404.

Goldstein AH, Danon A, Baertlein DA and McDaniel RG (1988) Phosphate inducible metabolism in Lycopersicon nesculentum: Characterization of acid phosphatase by tomato and suspension-cultured cells. Plant Physiol. 87: 716-720.

Granjeiro PA, Ferreira CV, Taga E M and Aoyama H (1999) Purification and kinetic properties of a castor bean seed acid phosphatase containing sulfhydryl groups. Plant Physiol. 107: 151-158.

Ilieva M, Bakalova A and Pavlov A (2000) Production of phosphohydrolases by Nicotiana tabacum 1507 cell suspension culture. Plant Cell Tiss. Org. Cult. 60: 155-158.

Lowry OH, Rosebrough, NJ, Farr AL and Randall RJ (1951) Protein measurement with Folin phenol reagent. J. Biol Chem. 193: 265-275.

Panara F, Pasqualini S and Antonielli M (1990) Multiple forms of barley root acid phosphatase: Purification and some characteristics of the major cytoplasmic isoenzyme. Biochem. Biophys. Acta. 1037: 73-80.

Staswick PE, Papa C, Huang JF and Rhee Y (1994) Purification of the major soybean leaf acid phosphatase that is increased by seed pod removal. Plant Physiol. 104: 49-57.

Sträter N, Fröhlich R, Schiemann A, Krebs B, Körner M, Suerbaum H and Witzel H (1992) Crystallization and preliminary crystallographic data of purple acid phosphatase from red kidney bean. J. Mol. Biol. 224(2): 511-513.

Su WW (1995) Bioprocessing technology for plant cell suspension cultures. Appl. Biochem. Biotechnol. 36: 341-351.

Tanaka H, Hirao C, Semba H, Tozawa Y and Ohmomo S (1985) Release of intracellularly stored 5'-phosphodiesterase with preserved plant cell viability. Biotechnol. Bioeng. 27: 890-892. 
Turner WL and Plaxton WC (2001) Purification and characterization of banana fruit acid phosphatase. Planta. 214: 243-249.

Ukita M, Furuya A, Tanaka H and Misawa M (1973) 5'-phosphodiesterase formation by cultured plant cells. Agr. Biol. Chem. 37: 2849-2854.

Zimmermann P, Regierer B, Kossmann J, Frossard E, Amrhein N and Bucher M (2004) Differential expression of three purple acid phosphatases from potato. Plant Biology. 6: 519-528. 